Article

\title{
First Case of Conyza canadensis from Hungary with Multiple Resistance to Glyphosate and Flazasulfuron
}

\author{
Candelario Palma-Bautista ${ }^{1}$ (1), Behroz Khalil Tahmasebi ${ }^{2}$, Pablo Tomás Fernández-Moreno ${ }^{3}$, \\ Antonia M. Rojano-Delgado ${ }^{1, *(1)}$, Ricardo Alcántara de la Cruz ${ }^{4}$ (i) and Rafael De Prado ${ }^{1(1)}$ \\ 1 Department of Agricultural Chemistry and Edaphology, University of Cordoba, 14071 Cordoba, Andalusia, \\ Spain; qe2pabac@uco.es (C.P.-B.); qe1pramr@uco.es (R.D.P.) \\ 2 Faculty of Agriculture, University of Mohaghegh Ardabili, Ardabil 56199-11367, Iran; \\ bhroz.weedscience@gmail.com \\ 3 Monsanto Europe SA, 1150 Brussels, Belgium; pablo.tomas.fernandez.moreno@monsanto.com \\ 4 Department of Entomology, Federal University of Viçosa, Viçosa, Minas Gerais 36570-900, Brazil; \\ ricardo.la@ufv.br \\ * Correspondence: q92rodea@uco.es; Tel.: +34-957-218-600
}

Received: 10 July 2018; Accepted: 13 August 2018; Published: 20 August 2018

\begin{abstract}
Conyza canadensis is a species invading large areas throughout the world, mainly due to its ability to evolve herbicide resistance. In Hungary, extensive areas have been infested by this species due to the difficulty in controlling it with glyphosate. To determine whether poor control was a result of misapplication or glyphosate resistance, eight suspected glyphosate-resistant $C$. canadensis populations from different Hungarian regions were studied. In whole-plant dose-response assays with glyphosate, the $\mathrm{LD}_{50}$ and $\mathrm{GR}_{50}$ values (survival and fresh weight reduction at $50 \%$ relative to the untreated control, respectively) indicated that resistance was confirmed in five of the eight populations (H-5 population being the most resistant). Additionally, the shikimic acid accumulation tests corroborated the results observed in the dose-response assays. 11 alternative herbicides from six different modes of action (MOA) were applied at field doses as control alternatives on populations $\mathrm{H}-5$ and $\mathrm{H}-6$ (both in the same regions). The H-5 population showed an unexpected resistance to flazasulfuron (ALS-inhibitor). The ALS enzyme activity studies indicated that the $\mathrm{I}_{50}$ for $\mathrm{H}-5$ with flazasulfuron was 63.3 times higher compared to its correspondent susceptible population (H-6). Therefore, the H-5 population exhibited multiple-resistance to flazasulfuron and glyphosate, being the first case reported in Europe for these two MOA.
\end{abstract}

Keywords: ALS-inhibitors; horseweed; multiple-resistance; alternative chemical control

\section{Introduction}

Herbicide resistance is an evolutionary phenomenon that allows weeds that are exposed to the recommended field dose of a herbicide to maintain growth with little or no symptomology [1]. Factors that are important for the selection of herbicide-resistant weed populations include a strict dependence on herbicides with the same mode of action (MOA) and its continuous use [2].

One of the most widely used herbicides over the last four decades has been glyphosate, which has a demonstrated high efficiency in weed control [3]. Its continued use however, together with the resistance evolution, have resulted in a large number of weed species resistant to glyphosate [4]. Amongst these are the three common species of Conyza genus (Conyza bonariensis (L.) Cronquist., C. canadensis (L.) Cronquist., and C. sumatrensis (Retz.) E. Walker), found in many countries [4-7].

The first case of glyphosate resistance in C. canadensis was confirmed in North America in 2000 [8]. Since then, there have been many cases of resistance observed in this genus around the world [4]. 
Conyza species are one of the most prone to evolve resistance to glyphosate. This incidence has been corroborated in Europe in a large number of populations.

The survival of resistant weeds after herbicide applications can occur because of two distinct resistance mechanisms: target-site resistance (TSR) and non-target site resistance (NTSR) [2]. The NTSR mechanisms are caused, for example, by reduced absorption and/or translocation, increased vacuolar sequestration [9], and/or metabolism into non-toxic compounds [10,11]. By contrast, the TSR mechanisms are caused by the increased expression of the target protein or structural changes in the herbicide-binding site $[12,13]$.

Another important problem is when multiple resistances or coexisting resistance mechanisms for different modes of action (MOA) herbicides in the population occur. Given its importance in agriculture, the most serious multiple herbicide resistance cases are those involving glyphosate. Half of the glyphosate-resistance cases around the world include cases of multiple resistance [4]. The continued use of herbicides with different MOA (i.e., acetolactate synthase-ALS-inhibitor) to control glyphosate-resistant weeds under non-herbicide-rotation regimes have resulted in decreased weed control efficiency [14], leading to the appearance of multiple resistance and reducing the alternatives for growers when acting against it.

Hungary is a country with significant agricultural activity, due in part to its favorable climatic conditions [15]. In recent years, Hungary has observed infestations of its crop fields (pastures, vineyards, and corn crops) by weeds-such as Cirsium arvense, Conyza canadensis, and Sorghum halepense-that are herbicide resistant (synthetic auxins, EPSPS inhibitors and ALS inhibitors, respectively). However, no studies have reported the resistance level in these C. canadensis which present multiple resistance. According to Heap [4] this would be the first case of multiple resistance to group $\mathrm{G}$ and $\mathrm{B}$ in Europe in this species.

The objectives of the present study were: to evaluate the level of glyphosate resistance in eight suspected C. canadensis populations from two different vineyard regions of Hungary; to evaluate chemical control alternatives in two glyphosate resistant populations; and to determine the level of multiple resistance if it was found.

\section{Materials and Methods}

\subsection{Plant Material}

Eight suspected glyphosate-resistant (GR) C. canadensis populations from two different regions of Hungary were studied. Populations were provided by Monsanto Europe and denominated as H-1 to H-8. Additionally, two populations, one GR and one GS (glyphosate-susceptible) of C. canadensis, (characterized as the R and S-glyphosate populations by University of Cordoba, Spain, respectively) were compared to the Hungarian populations (Table 1). In all cases, seeds were taken from 10 mature plants in vineyard crop and non-crop areas.

Table 1. Conyza canadensis populations harvested in different Hungarian (HUN) and Spanish (ESP) areas.

\begin{tabular}{|c|c|c|c|c|c|}
\hline Population & Location & Crops & Herbicide Application & Dose/Year & Coordinate \\
\hline GR & Córdoba/ESP & Olive grove & Glyphosate & $1440^{a} / 20$ & $37.999,-4.448$ \\
\hline GS & Córdoba/ESP & Railway & Mechanical control & & $37.916,-4.717$ \\
\hline $\mathrm{H}-1$ & Badacsony/HUN & Vineyard & Glyphosate + 2,4-D & $1440^{a} / 10+600^{b} / 5$ & $46.786,17.382$ \\
\hline $\mathrm{H}-2$ & Badacsony/HUN & Vineyard & Glyphosate + flazasulfuron & $1440^{a} / 10+750^{c} / 4$ & $46.790,17.428$ \\
\hline $\mathrm{H}-3$ & Badacsony/HUN & Vineyard & Glyphosate & $1800^{a} / 20$ & $46.785,17.449$ \\
\hline $\mathrm{H}-4$ & Balaton/HUN & Vineyard & Glyphosate & $1800^{a} / 20$ & $46.787,17.716$ \\
\hline $\mathrm{H}-5$ & Balaton/HUN & Vineyard & Glyphosate + flazasulfuron & $1800^{a} / 20+750^{c} / 7$ & $46.788,17.770$ \\
\hline H-6 & Balaton/HUN & Vineyard & Organic crop & $-/ 20$ & $46.811,17.830$ \\
\hline $\mathrm{H}-7$ & Balaton/HUN & No crop & No herbicide & - & $46.871,17.944$ \\
\hline $\mathrm{H}-8$ & Badacsony/HUN & Vineyard & Organic crop & $-/ 10$ & $46.787,17.487$ \\
\hline
\end{tabular}


Mature seeds were germinated in Petri dishes with filter paper moistened with distilled water. Petri dishes were placed in a growth chamber at $28 / 18^{\circ} \mathrm{C}$ (day/night) with a photoperiod of $16 \mathrm{~h}$, $850 \mu \mathrm{mol} \mathrm{m} \mathrm{m}^{-2} \mathrm{~s}^{-1}$ photosynthetic photon flux, and $80 \%$ relative humidity. Seedlings from each population were transplanted individually into plastic pots $\left(448 \mathrm{~cm}^{3}\right)$ containing sand/peat at a 1:2 $(v / v)$ ratio, and they were then placed in a greenhouse at $28 / 18^{\circ} \mathrm{C}$ (day/night).

\subsection{Dose-Response Assays with Glyphosate}

Conyza canadensis plants were treated with glyphosate at the rosette stage (BBCH 16-18 stage) [16]. Herbicide treatments were carried out in a laboratory chamber sprayer (SBS-060 De Vries Manufacturing, Hollandale, MN, USA) equipped with an $8002 \mathrm{E}$ flat fan nozzle delivering $200 \mathrm{~L} \mathrm{ha}^{-1}$ at $250 \mathrm{kPa}$ at a height of $50 \mathrm{~cm}$. The different glyphosate doses are shown in Table 2. Plant survival, i.e., plants that survived the herbicide treatment, was recorded at 28 days after treatment (DAT). The plants were then harvested at the ground level and weighed to determine their fresh weight. Fresh weight and survival data were converted to percentages in comparison with the untreated control plants. All populations were compared to the GS population.

The experiment was repeated three times with five replicates per treatment and population combination.

Table 2. Herbicides, formulation (type and concentration) a /manufacturer, HRAC group, doses used in the curve dose-response in $\mathrm{g}$ ai ha ${ }^{-1}$ (Dose-response), and recommended field doses in $\mathrm{g}$ ai ha $\mathrm{ha}^{-1}$ (Dose) applied on C. canadensis populations from Spain (GR and GS) and Hungary (H1-H8) at the rosette stage (BBCH 16-18).

\begin{tabular}{|c|c|c|c|c|}
\hline Herbicide & HRAC $^{b}$ & Formulation/Manufacturer & Dose-Response & Dose \\
\hline Glyphosate $^{c}$ & G & $\begin{array}{l}\text { Roundup Energy }{ }^{\circledR} \\
(\mathrm{SL} 50.9 \% w / v) / \text { Monsanto }^{\circ}\end{array}$ & $\begin{array}{c}0 / 31.25 / 62.5 / 125 / 250 / 500 / \\
1000 / 2000 / 4000 / 6000\end{array}$ & 1080 \\
\hline Flazasulfuron & $\mathrm{B}$ & Terafit $^{\circledR}($ WG 25\% $w / w) /$ Syngenta & $0 / 5 / 10 / 20 / 40 / 50 / 100 / 200$ & 80 \\
\hline 2,4-D & $\mathrm{O}$ & U46 D Complet ${ }^{\circledR}(\mathrm{SL}, 60 \% w / v) /$ Nufarm & $0 / 45 / 90 / 180 / 360 / 720 / 1200$ & 600 \\
\hline Carfentrazone & $\mathrm{E}$ & Affinity $240 \mathrm{CE}^{\circledR}(\mathrm{CE} 22.3 \% w / v) / \mathrm{FMC}$ & 0/3.75/7.5/15/30/60/100 & 100 \\
\hline Flumioxazin & $\mathrm{E}$ & Pledge ${ }^{\circledR}(\mathrm{WP} 50 \%$ w/w)/Kenogard & $0 / 25 / 50 / 100 / 300 / 600$ & 400 \\
\hline Fomesafen & $\mathrm{E}$ & Flex $25 \mathrm{SL}^{\circledR}(25 \% w / v) /$ Syngenta & 0/50/100/200/300/600 & 400 \\
\hline MCPA & $\mathrm{O}$ & U 46 SP Fluid ${ }^{\circledR}($ SL $40 \% p / v) /$ Nufarm & $0 / 250 / 500 / 750 / 1000 / 2000$ & 1000 \\
\hline Pyraflufen-ethyl & $\mathrm{E}$ & Gozai ${ }^{\circledR} \mathrm{CE}, 2.65 \%$ w/v)/Belchim & $0 / 1 / 2 / 3 / 6 / 8$ & 6.62 \\
\hline Glufosinate & $\mathrm{H}$ & Finale $^{\circledR}(\mathrm{SL}, 20 \% w / v) /$ BayerCropScience & $\begin{array}{c}0 / 31.25 / 62.5 / 125 / 250 / \\
500 / 1000 / 2000 / 4000\end{array}$ & 750 \\
\hline
\end{tabular}

${ }^{a}$ Formulation type: SL, soluble (liquid) concentrate; SC, suspension concentrate; WG, water dispersible granules; EC, emulsifiable concentrate; WP, wettable powder. Concentration in percentage: $w / w=$ weight/weight or $w / v=$ weight/volume. Mention of trade names in this publication is solely for providing specific information and does not imply their recommendation. ${ }^{b}$ HRAC: Herbicide-Resistance Action Committee; G: EPSPS inhibitors; B: ALS inhibitors; O: Synthetic auxins; E: PPO inhibitors; F1: PDS inhibitors; H: Glutamine synthase inhibitors; D: PSI electron diverter. ${ }^{c}$ Doses expressed as g acid equivalent $(\mathrm{ae}) \mathrm{ha}^{-1}(50.9 \%$ potassium salt of glyphosate equals $450 \mathrm{~g}$ ae $^{-1}$ ).

\subsection{Shikimic Acid Accumulation}

Leaf disks of 4-mm diameter were harvested from the youngest fully expanded leaf at the BBCH 16-18 stage from each C. canadensis population. Shikimate accumulation was determined according to Dayan et al. [17] and Hanson et al. [18]. The disks of fresh tissue $(\sim 50 \mathrm{mg})$ from each population were transferred to $2 \mathrm{~mL}$ Eppendorf tubes containing $1 \mathrm{~mL}$ of $1 \mathrm{mM} \mathrm{NH}_{4} \mathrm{H}_{2} \mathrm{PO}_{4}$ (pH 4.4). At this point, $1 \mu \mathrm{L}$ of glyphosate at different concentrations was added to each tube resulting in the following concentrations: 0 (blank), 10, 50, 100, 500, and $1000 \mu \mathrm{M}$. The Eppendorfs were incubated in a growth chamber for $24 \mathrm{~h}$ under the above temperature, humidity, and light conditions. After $24 \mathrm{~h}$, the tubes were stored at $-20{ }^{\circ} \mathrm{C}$ for further analysis. For analysis, tubes were thawed at $60{ }^{\circ} \mathrm{C}$ for $30 \mathrm{~min}$. Thereafter, $250 \mu \mathrm{L}$ of $1.25 \mathrm{~N} \mathrm{HCl}$ were added to each Eppendorf tube and shaken with the mechanical 
stirrer Selecta (Barcelona, Spain) for $5 \mathrm{~min}$. The tubes were incubated at $60^{\circ} \mathrm{C}$ for $15 \mathrm{~min}$ and then shaken again for the same period. A $125 \mu \mathrm{L}$ aliquot from each Eppendorf tube was pipetted into a new $2 \mathrm{~mL}$ Eppendorf tube, and $500 \mu \mathrm{L}$ of periodic acid and sodium metaperiodate $(0.25 \%(w / v)$ each) were added. After incubation at room temperature for $90 \mathrm{~min}, 500 \mu \mathrm{L}$ of $0.6 \mathrm{~N}$ sodium hydroxide and $0.22 \mathrm{M}$ sodium sulfite were added. Finally, the liquid in the tubes was transferred to glass vials. Within $30 \mathrm{~min}$, the light absorption at $380 \mathrm{~nm}$ was measured in a spectrophotometer mod. DU-640 from Beckman Coulter (Fullerton, CA, USA). This experiment was replicated three times with five repetitions for glyphosate concentration and population in a randomized design.

\subsection{Dose-Response Assays with Alternative Herbicides}

To evaluate the potential efficacy of an integrated weed management (IWM) program and screening for potential multiple herbicide resistances, alternative herbicides were applied at the same conditions and spraying volume as the previous assay on the H-5 and H-6 C. canadensis populations, which presented the highest and lowest $\mathrm{LD}_{50}$ values for glyphosate, respectively. The different herbicides and doses used are shown in Table 2. H-5 was compared to the H-6 population, which was considered susceptible and from the same region (Balaton, Hungary). Plants were cut at 28 DAT, and $\mathrm{GR}_{50}$ and $\mathrm{LD}_{50}$ values were determinate. Treatments were replicated three times in a completely randomized design using five plants per dose and population.

\subsection{ALS Enzyme Activity}

Three grams of young leaf tissues were harvested from the H-5 and H-6 populations according to Hatami et al. [19]. They were ground with liquid $\mathrm{N}_{2}$ and mixed with an extraction buffer in a proportion of 1:2 (tissue: buffer). This buffer was composed of $0.5 \mathrm{~g}$ in polyvinylpyrrolidone (PVP), $1 \mathrm{M}$ K-phosphate (at $\mathrm{pH} 7.5$ ), $10 \mathrm{mM}$ sodium pyruvate, $5 \mathrm{mM} \mathrm{MgCl}_{2}, 50 \mathrm{mM}$ thiamine pyrophosphate, $100 \mu \mathrm{M}$ flavint adenine dinucleotide (FAD), $12 \mathrm{mM}$ dithiothreitol, and glycerol (1:9 v/v). The mix was agitated for $10 \mathrm{~min}$ at $4{ }^{\circ} \mathrm{C}$ in a magnetic stirrer from Bunsen (Humanes de Madrid, Spain). The homogenate was filtered through four layers of cheesecloth and centrifuged in an Avanti J-25 Beckman Coulter centrifuge (Fullerton, CA, USA) at 20,000 rpm for $20 \mathrm{~min}$. The supernatant contained a crude ALS enzyme extract, which was immediately used for the enzyme assays.

The ALS activity was assayed by adding $0.09 \mathrm{~mL}$ of enzyme extract to $0.11 \mathrm{~mL}$ of freshly prepared assay buffer (0.08 M K-phosphate buffer solution at $\mathrm{pH} 7.5,0.5 \mathrm{M}$ sodium pyruvate, $0.1 \mathrm{M} \mathrm{MgCl}$, $0.5 \mathrm{mM}$ thiamine pyrophosphate, and $1 \mu \mathrm{M} \mathrm{FAD}$ ) containing increasing concentrations of flazasulfuron (Sulfonylureas): $0,1,5,10,50,100,500,1000,5000$, and 10,000 $\mu \mathrm{M}$. A solution of $0.04 \mathrm{M} \mathrm{K}_{2} \mathrm{HPO}_{4}$ ( $\mathrm{pH}$ 7.0) was added to complete a final volume of $0.25 \mathrm{~mL}$. This mixture was incubated at $37^{\circ} \mathrm{C}$ for one hour. The reaction was stopped with $50 \mu \mathrm{L}$ of $\mathrm{H}_{2} \mathrm{SO}_{4}$. (1:50 v/v) and heated at $60{ }^{\circ} \mathrm{C}$ for $15 \mathrm{~min}$. An aliquot of $0.25 \mathrm{~mL}$ creatine $\left(5 \mathrm{~g} \mathrm{~L}^{-1}\right.$ freshly prepared in water) and $0.25 \mathrm{~mL}$ of 1-naphthol (50 g L ${ }^{-1}$ freshly prepared in $5 \mathrm{~N} \mathrm{NaOH}$ ) were added followed by incubation at $60{ }^{\circ} \mathrm{C}$ for $15 \mathrm{~min}$. The acetoin from decarboxylate acetolactate was detected as a colored complex $\left(\mathrm{A}_{520} \mathrm{~nm}\right)$ in the spectrophotometer. The background was subtracted using control tubes in which the reaction was stopped prior to incubation.

The protein was determined using the Bradford method [20] in which an acidic solution of Coomassie Brilliant Blue G-250 was used for protein binding. The absorbance used for measurement was $595 \mathrm{~nm}$. The maximum ALS-specific activity (nmol acetoin $\mathrm{mg}^{-1} \mathrm{STP} \mathrm{h}^{-1}$ ) was measured without herbicide.

The experiment was performed three times with five repetitions per herbicide concentration and population following a randomized design.

\subsection{Statistical Analysis}

To determine the dose of glyphosate and alternatives herbicides needed to reduce the fresh weight $\left(\mathrm{GR}_{50}\right)$, cause mortality $\left(\mathrm{LD}_{50}\right)$, or inhibit the ALS activity $\left(\mathrm{I}_{50}\right)$ by $50 \%$, the data of dose-response and 
ALS enzyme activity assays were subjected to non-linear regression analysis using a three-parameter $\log$-logistic Equation (1)

$$
y=\left(\left[(d) / 1+(x / g)^{b}\right]\right)
$$

where $y$ is the fresh weight, survival, or enzyme activity expressed as the percentage in relation to the non-treated control; $d$ is the coefficient corresponding to the upper asymptote; $b$ is the slope of the line; $g$ is the $\mathrm{GR}_{50}, \mathrm{LD}_{50}$, or $\mathrm{I}_{50}$; and $x$ (independent variable) is the herbicide dose/concentration.

The $d r c$ package in $\mathrm{R}$ (version 3.2.5) was used to conduct the regression analyses [21]. Plots were generated with SigmaPlot 11.0 (Systat Software, Inc., San Jose, CA, USA). Resistance factors (RF) were obtained as R-to-S $\mathrm{GR}_{50}, \mathrm{LD}_{50}$, or $\mathrm{I}_{50}$ ratios. A lack-of-fit test was used to compare the model that consisted of curves with population-specific $g$ values to a reduced model with a common $g$ [21].

Statistix 9.0 (Analytical Software, Tallahassee, FL, USA) was used to conduct the analysis of variance (ANOVA) to test for differences between populations in terms of the shikimic acid accumulation. Differences of $p<0.05$ between means were considered significant and separated using the Tukey HSD test.

\section{Results}

\subsection{Dose-Response Assays with Glyphosate}

Numerical differences were observed in the $\mathrm{GR}_{50}$ and $\mathrm{LD}_{50}$ values of the Hungarian populations in comparison to the GR and GS populations from Spain (used as references) (Figure 1). Of the eight populations studied, the $\mathrm{H}-4(\mathrm{RF} \approx 11)$ and $\mathrm{H}-5(\mathrm{RF} \approx 13)$ populations showed the largest resistance factors $(\mathrm{RF})$ based on the $\mathrm{LD}_{50}$ values, followed by the H-2 $(\mathrm{RF} \approx 10), \mathrm{H}-3(\mathrm{RF} \approx 9)$, and $\mathrm{H}-1(\mathrm{RF} \approx 9)$ populations. These five populations survived at the recommended field dose and had values similar to the GR C. canadensis used as a references. By contrast, the H-6, H-7, and H-8 populations were susceptible to glyphosate. Differences between these three populations, compared to the GS population used as a reference, were not found. However, a difference of almost $200 \mathrm{~g}$ ae ha ${ }^{-1}$ based on the $\mathrm{LD}_{50}$ values between the H-8 and GS populations was observed (Table 3).

Table 3. Parameters of the log-logistic equations ${ }^{a}$ used to calculate the glyphosate rates $\left(\mathrm{g}\right.$ ea ha ${ }^{-1}$ ) required for $50 \%$ survival $\left(\mathrm{LD}_{50}\right)$, or reduction fresh weight $\left(\mathrm{GR}_{50}\right)$ of $C$. canadensis populations from Spain (GR and GS) and Hungary (H1-H8).

\begin{tabular}{ccccccccccc}
\hline Population & $\boldsymbol{d}$ & $\boldsymbol{b}$ & LD $_{\mathbf{5 0}}$ & $\mathbf{R F}{ }^{*}$ & $\boldsymbol{P}$ & $\boldsymbol{d}$ & $\boldsymbol{b}$ & $\mathbf{G R}_{\mathbf{5 0}}$ & $\mathbf{R F}^{*}$ & $\boldsymbol{P}^{*}$ \\
GR & 100.3 & 4.53 & $3453.6 \pm 91.4$ & & & 100.0 & 2.03 & $1474.0 \pm 106.4$ & 30.5 & 0.0001 \\
GS & 102.1 & 1.81 & $305.7 \pm 33.1$ & 11.3 & 0.0001 & 101.3 & 4.23 & $48.3 \pm 4.3$ & \\
H-1 & 98.9 & 3.33 & $2761.8 \pm 62.5$ & 9.0 & 0.0001 & 98.7 & 1.26 & $574.5 \pm 38.6$ & 11.9 & 0.0001 \\
H-2 & 100.2 & 6.96 & $3055.8 \pm 87.2$ & 10. & 0.0001 & 98.3 & 1.08 & $500.1 \pm 29.8$ & 10.3 & 0.0001 \\
H-3 & 99.3 & 5.88 & $2937.7 \pm 83.8$ & 9.6 & 0.0001 & 99.6 & 1.10 & $990.9 \pm 102.4$ & 20.5 & 0.0001 \\
H-4 & 99.6 & 5.72 & $3358.6 \pm 102.9$ & 11.0 & 0.0001 & 99.7 & 1.46 & $995.5 \pm 74.4$ & 20.6 & 0.0001 \\
H-5 & 100.0 & 3.18 & $4029.4 \pm 115.4$ & 13.2 & 0.0001 & 99.9 & 0.82 & $638.4 \pm 21.5$ & 13.2 & 0.0001 \\
H-6 & 100.4 & 4.20 & $383.0 \pm 21.9$ & 1.5 & 0.2671 & 100.5 & 1.67 & $83.3 \pm 5.4$ & 1.7 & 0.1227 \\
H-7 & 100.9 & 5.09 & $436.4 \pm 38.9$ & 1.4 & 0.1089 & 102.4 & 1.33 & $89.4 \pm 9.6$ & 1.8 & 0.1098 \\
H-8 & 99.3 & 3.78 & $493.2 \pm 17.5$ & 1.6 & 0.3516 & 100.5 & 1.76 & $79.7 \pm 12.0$ & 1.6 & 0.2539 \\
\hline
\end{tabular}

${ }^{\mathrm{a}} \mathrm{Y}=\mathrm{d} / 1+(\mathrm{x} / \mathrm{g})^{\mathrm{b}}$ : where $\mathrm{Y}=$ percentage of survival or fresh weight with respect to the control, $\mathrm{d}=\mathrm{upper}$ limit, $b=$ slope of the curve, $g=$ herbicide dose at the inflection point (i.e., $\mathrm{LD}_{50}$ or $\mathrm{GR}_{50}$ ), and $\mathrm{x}=$ herbicide dose. Resistance factor $\left(\mathrm{RF}=\mathrm{LD}_{50}\right.$ or $\mathrm{GR}_{50}$ of a resistant population/LD $\mathrm{LD}_{50}$ or $\mathrm{GR}_{50}$ of GS). 

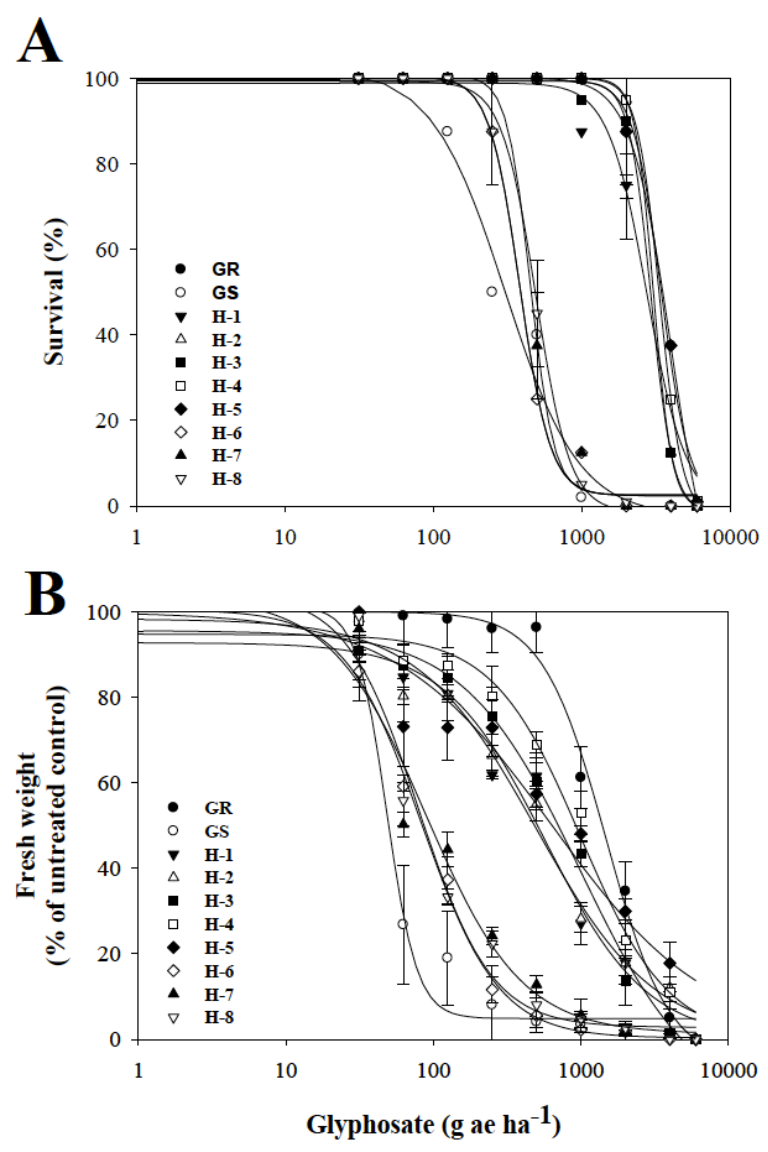

Figure 1. Glyphosate dose-response on (A) survival and (B) fresh weight reduction expressed as a percentage of the mean untreated control of the populations of $C$. canadensis from Spain (GR and GS) and Hungary $(\mathrm{H} 1-\mathrm{H} 8)$. Symbols denote the mean $(n=15) \pm$ standard errors.

\subsection{Shikimic Acid Accumulation}

From 10 to $500 \mu \mathrm{M}$ of glyphosate, the accumulation of shikimic acid increased slightly in each population. At $500 \mu \mathrm{M}$, the accumulation increased strongly, with the largest amount occurring at $1000 \mu \mathrm{M}$. The R-populations (H-1, H-2, H-3, H-4, H-5, and GR) accumulated approximately four-fold less shikimic acid at $1000 \mu \mathrm{M}$ compared to the H-6, H-7, H-8, and GS populations (Table 4).

Table 4. Shikimic acid accumulation ( $\mu \mathrm{g}$ of shikimic acid $\mathrm{g}^{-1}$ fresh weight) at different glyphosate concentrations $(\mu \mathrm{M})$ in C. canadensis populations from Spain (GR and GS) and Hungary (H1-H8).

\begin{tabular}{cccccc}
\hline \multirow{2}{*}{ Populations } & \multicolumn{5}{c}{ Glyphosate Concentration } \\
\cline { 2 - 6 } & $\mathbf{1 0}$ & $\mathbf{5 0}$ & $\mathbf{1 0 0}$ & $\mathbf{5 0 0}$ & $\mathbf{1 0 0 0}$ \\
\hline GR & $4.3 \pm 0.7 \mathrm{G}$ & $23.5 \pm 3.9 \mathrm{DE}$ & $54.9 \pm 6.4 \mathrm{C}$ & $63.1 \pm 7.3 \mathrm{~B}$ & $65.8 \pm 6.1 \mathrm{~B}$ \\
GS & $10.2 \pm 1.8 \mathrm{EF}$ & $78.7 \pm 7.6 \mathrm{~B}$ & $160.4 \pm 15.3 \mathrm{~B}$ & $273.7 \pm 23.1 \mathrm{~A}$ & $289.5 \pm 24.3 \mathrm{~A}$ \\
$\mathbf{H}-\mathbf{1}$ & $6.2 \pm 1.3 \mathrm{G}$ & $20.1 \pm 4.6 \mathrm{E}$ & $60.1 \pm 8.1 \mathrm{C}$ & $66.7 \pm 5.5 \mathrm{~B}$ & $71.5 \pm 7.5 \mathrm{~B}$ \\
$\mathbf{H}-\mathbf{2}$ & $13.9 \pm 2.1 \mathrm{CDE}$ & $22.0 \pm 2.6 \mathrm{DE}$ & $56.6 \pm 6.9 \mathrm{C}$ & $62.5 \pm 7.0 \mathrm{~B}$ & $69.4 \pm 5.4 \mathrm{~B}$ \\
$\mathbf{H}-3$ & $10.5 \pm 3.3 \mathrm{DEF}$ & $25.5 \pm 3.0 \mathrm{CD}$ & $61.8 \pm 5.4 \mathrm{C}$ & $70.4 \pm 6.1 \mathrm{~B}$ & $76.0 \pm 8.3 \mathrm{~B}$ \\
$\mathbf{H}-\mathbf{4}$ & $7.7 \pm 2.5 \mathrm{FG}$ & $29.1 \pm 4.4 \mathrm{C}$ & $52.3 \pm 7.1 \mathrm{C}$ & $64.5 \pm 5.8 \mathrm{~B}$ & $71.5 \pm 7.1 \mathrm{~B}$ \\
$\mathbf{H}-5$ & $14.3 \pm 3.8 \mathrm{BCD}$ & $25.1 \pm 3.7 \mathrm{CDE}$ & $61.3 \pm 6.5 \mathrm{C}$ & $68.3 \pm 7.3 \mathrm{~B}$ & $75.0 \pm 6.4 \mathrm{~B}$ \\
$\mathbf{H}-6$ & $18.2 \pm 3.1 \mathrm{AB}$ & $83.9 \pm 6.1 \mathrm{~A}$ & $176.5 \pm 20.1 \mathrm{AB}$ & $250.9 \pm 24.3 \mathrm{~A}$ & $276.8 \pm 29.2 \mathrm{~A}$ \\
$\mathbf{H}-\mathbf{7}$ & $16.9 \pm 2.4 \mathrm{ABC}$ & $75.6 \pm 7.4 \mathrm{~B}$ & $171.9 \pm 17.6 \mathrm{AB}$ & $268.8 \pm 27.3 \mathrm{~A}$ & $283.2 \pm 25.1 \mathrm{~A}$ \\
H-8 & $20.1 \pm 5.4 \mathrm{~A}$ & $80.4 \pm 6.0 \mathrm{AB}$ & $182.7 \pm 18.3 \mathrm{AB}$ & $276.3 \pm 30.6 \mathrm{~A}$ & $288.9 \pm 27.4 \mathrm{~A}$ \\
\hline
\end{tabular}

Means with different letter within are statistically different at $95 \%$ probability determined by the Tukey's test. \pm Standard error of the mean $(n=15)$. 


\subsection{Dose-Response Assays with Alternative Herbicides}

The H-6 population from Hungary, that was susceptible to glyphosate, was compared with the H-5 population (the most resistant to glyphosate) in order to avoid variant factors. The resistant factors (RF) obtained for $\mathrm{GR}_{50}$ and $\mathrm{LD}_{50}$ values of the alternative herbicides with different MOAs were close to unity, except for $\mathrm{H}-5$ with flazasulfuron (Table 5). The $\mathrm{LD}_{50}$ value of the H-5 population with flazasulfuron was two times higher than the recommended field dose and was 27.8 times more resistant than for the H-6 population (Figure 2).
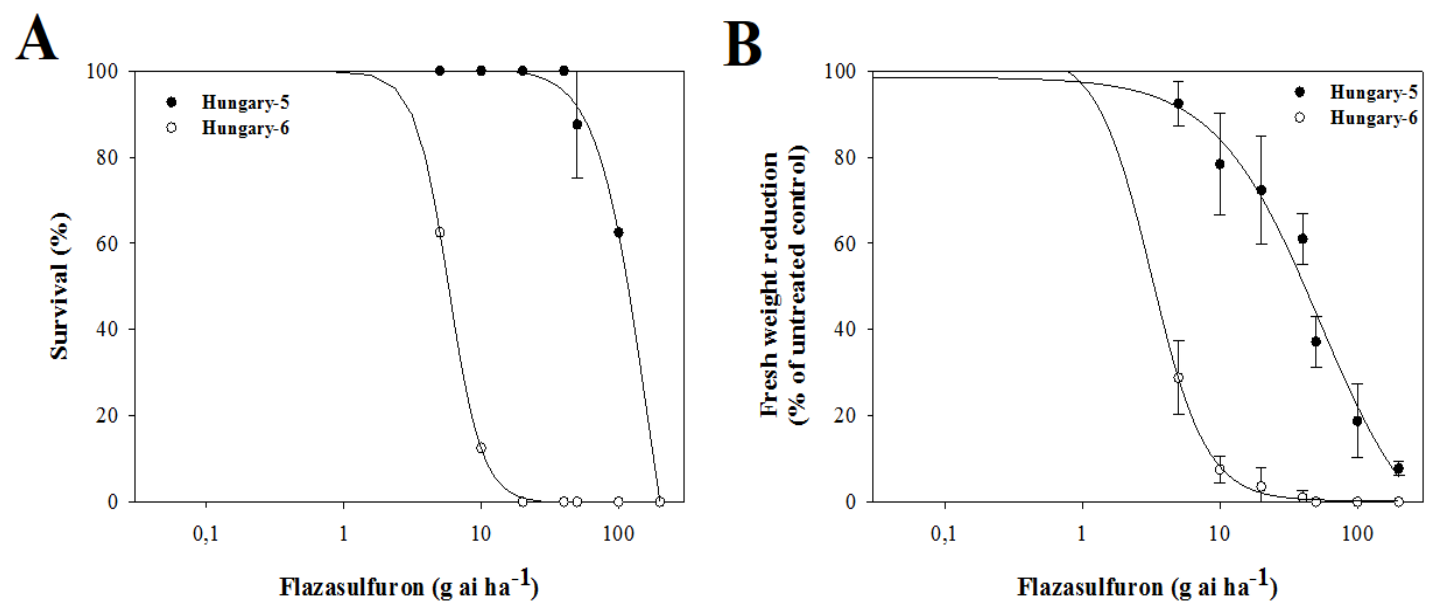

Figure 2. Flazasulfuron dose-response on (A) survival and (B) fresh weight reduction expressed as a percentage of the mean untreated control of the populations of C. canadensis from Spain (GR and GS) and Hungary $(\mathrm{H} 1-\mathrm{H} 8)$. Symbols denote the mean $(n=15) \pm$ standard errors. 
Table 5. Parameters of the log-logistic equations ${ }^{\text {a }}$ used to calculate the herbicide rates ( $\mathrm{g}$ ea ha ${ }^{-1}$ ) required for $50 \%$ survival $\left(\mathrm{LD}_{50}\right)$, or reduction fresh weight $\left(\mathrm{GR}_{50}\right)$ of C. canadensis populations H-5 and H-6 from Hungary $(n=15)$.

\begin{tabular}{|c|c|c|c|c|c|c|c|c|c|c|c|}
\hline \multicolumn{2}{|c|}{ Herbicide/Population } & \multirow{3}{*}{$\begin{array}{c}d \\
100.6 \\
100.0\end{array}$} & \multirow{3}{*}{$\begin{array}{c}\boldsymbol{b} \\
2.41 \\
3.55\end{array}$} & \multirow{3}{*}{$\begin{array}{c}\text { LD }_{50} \\
161.2 \pm 24.4 \\
5.8 \pm 0.4\end{array}$} & \multirow{3}{*}{$\begin{array}{l}\mathbf{R F}^{*} \\
27.9\end{array}$} & \multirow{3}{*}{$\frac{P}{0.0001}$} & \multirow{3}{*}{$\begin{array}{c}d \\
98.5 \\
102.5\end{array}$} & \multirow{3}{*}{$\begin{array}{c}\boldsymbol{b} \\
1.15 \\
2.18\end{array}$} & \multirow{3}{*}{$\begin{array}{c}\mathbf{G R}_{\mathbf{5 0}} \\
52.6 \pm 5.7 \\
3.2 \pm 0.3\end{array}$} & \multirow{3}{*}{$\begin{array}{l}\mathbf{R F}^{*} \\
16.5\end{array}$} & \multirow{3}{*}{$\begin{array}{c}\boldsymbol{P} \\
0.0001\end{array}$} \\
\hline & H-5 & & & & & & & & & & \\
\hline Flazasulfuron & H-6 & & & & & & & & & & \\
\hline \multirow{2}{*}{$2,4-D$} & H-5 & 102.7 & 2.11 & $184.4 \pm 21.0$ & \multirow{2}{*}{1.1} & \multirow{2}{*}{0.3902} & 99.3 & 0.82 & $124.8 \pm 25.4$ & \multirow[b]{2}{*}{1.6} & \multirow{2}{*}{0.0968} \\
\hline & H-6 & 101.6 & 1.72 & $164.8 \pm 22.7$ & & & 102.3 & 0.87 & $79.5 \pm 18.6$ & & \\
\hline \multirow{2}{*}{ Carfentrazone } & H-5 & 100.9 & 2.64 & $30.9 \pm 0.8$ & \multirow{2}{*}{1.3} & \multirow{2}{*}{0.2571} & 99.0 & 1.13 & $19.1 \pm 1.7$ & \multirow{2}{*}{1.3} & \multirow{2}{*}{0.2861} \\
\hline & H-6 & 100.4 & 1.76 & $23.6 \pm 1.6$ & & & 100.6 & 1.14 & $15.1 \pm 2.4$ & & \\
\hline \multirow{2}{*}{ Flumioxazin } & H-5 & 100.3 & 2.92 & $200.6 \pm 25.9$ & \multirow{2}{*}{1.4} & \multirow{2}{*}{0.0984} & 101.4 & 0.97 & $75.7 \pm 7.9$ & \multirow{2}{*}{1.6} & \multirow{2}{*}{0.3875} \\
\hline & H-6 & 103.3 & 2.01 & $141.5 \pm 20.6$ & & & 99.9 & 0.79 & $47.4 \pm 10.8$ & & \\
\hline \multirow{2}{*}{ Fluroxypyr } & H-5 & 101.3 & 3.75 & $114.8 \pm 4.6$ & \multirow{2}{*}{1.1} & \multirow{2}{*}{0.0996} & 100.0 & 3.31 & $28.7 \pm 1.2$ & \multirow{2}{*}{1.2} & \multirow{2}{*}{0.4392} \\
\hline & H-6 & 100.5 & 2.69 & $101.2 \pm 2.3$ & & & 100.3 & 2.90 & $24.5 \pm 4.0$ & & \\
\hline \multirow{2}{*}{ Diflufenican } & H-5 & 101.0 & 3.01 & $258.0 \pm 32.2$ & & & 101.3 & 2.99 & $208.7 \pm 13.8$ & & \\
\hline & H-6 & 101.3 & 5.86 & $231.4 \pm 9.3$ & 1.1 & 0.1583 & 100.5 & 2.78 & $183.3 \pm 10.8$ & 1.1 & 0.2447 \\
\hline & H-5 & 102.1 & 3.53 & $206.8 \pm 15.5$ & & & 98.5 & 1.66 & $189.2 \pm 17.7$ & & \\
\hline Fomesaten & H-6 & 99.1 & 3.58 & $198.6 \pm 10.9$ & 1.0 & 0.1034 & 97.1 & 1.65 & $131.2 \pm 21.8$ & 1.4 & 0.2816 \\
\hline MCPA & H-5 & 100.4 & 6.03 & $545.2 \pm 12.3$ & & & 99.9 & 0.97 & $172.3 \pm 21.1$ & & \\
\hline IVCPA & H-6 & 96.8 & 4.13 & $506.01 \pm 27.7$ & 1.0 & 0.2190 & 100.0 & 0.93 & $130.3 \pm 18.4$ & 1.3 & 0.1648 \\
\hline Pyraflufen-ethyl & H-5 & 96.3 & 6.03 & $2.2 \pm 0.1$ & & 01602 & 99.9 & 1.02 & $1.3 \pm 0.3$ & & \\
\hline ryramuren-etnyi & H-6 & 97.4 & 3.88 & $2.0 \pm 0.1$ & 1.1 & 0.1693 & 100.0 & 1.39 & $1.2 \pm 0.2$ & 1.1 & 0.1739 \\
\hline & H-5 & 100.6 & 2.47 & $77.7 \pm 6.0$ & 12 & 03591 & 101.5 & 2.05 & $46.1 \pm 4.4$ & 12 & 01520 \\
\hline Glutosinate & H-6 & 100.1 & 3.66 & $62.8 \pm 3.5$ & 1.2 & 0.3591 & 102.8 & 3.23 & $38.1 \pm 5.5$ & 1.2 & $0.15<0$ \\
\hline Diauat & H-5 & 100.3 & 1.77 & $14.1 \pm 1.9$ & 13 & 02745 & 102.0 & 0.98 & $7.3 \pm 0.6$ & 13 & 03435 \\
\hline Diquat & H-6 & 99.9 & 2.42 & $11.1 \pm 1.4$ & 1.3 & $0.2 / 45$ & 101.1 & 1.11 & $5.7 \pm 0.3$ & 1.3 & 0.3435 \\
\hline
\end{tabular}

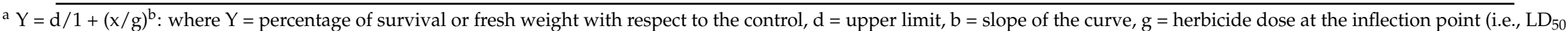
or $\left.\mathrm{GR}_{50}\right)$, and $\mathrm{x}=$ herbicide dose. Resistance factor $\left(\mathrm{RF}=\mathrm{LD}_{50}\right.$ or $\mathrm{GR}_{50}$ of a resistant population $/ \mathrm{LD}_{50}$ or $\mathrm{GR}_{50}$ of GS). 


\subsection{ALS Enzyme Activity}

The $\mathrm{I}_{50}$ values determined for the $\mathrm{H}-5$ and $\mathrm{H}-6$ populations were $603.7 \pm 17.6$ and $9.5 \pm 1.6 \mu \mathrm{M}$, flazazulfuron respectively. These results indicated that resistance to this herbicide was 63.3 times higher in the H-5 population than in the H-6 population (Figure 3).

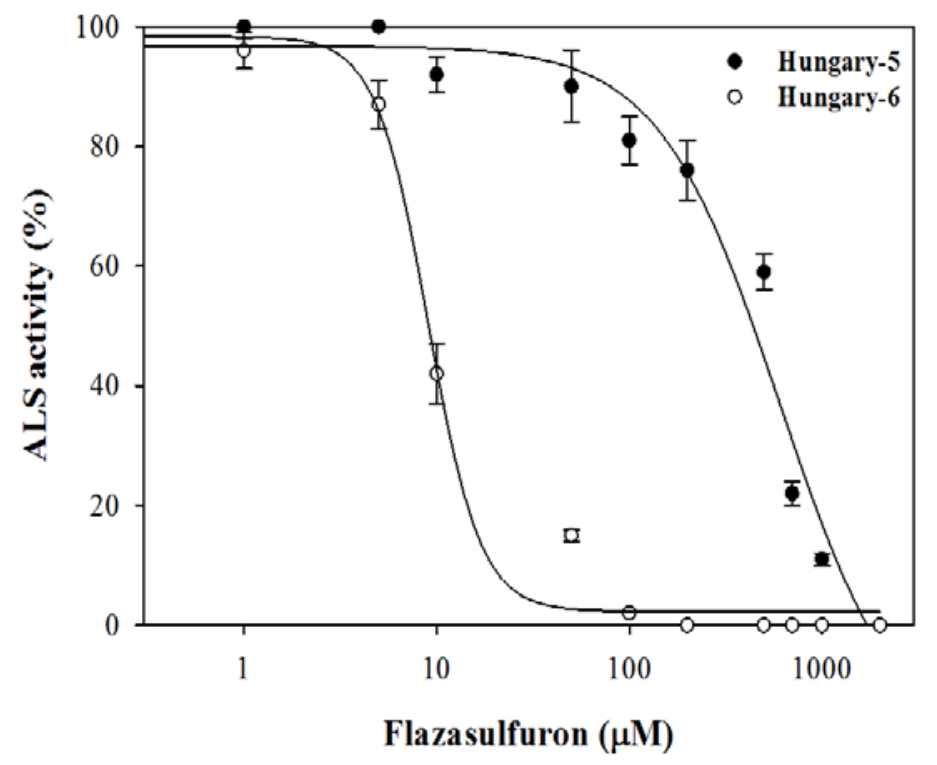

Figure 3. ALS enzyme activity was determined using flazasulfuron in the $\mathrm{H}-5$ and -6 populations from Hungary. The equations of log-logistic curves to estimates the $\mathrm{I}_{50}$ values are: H-5: $Y=\left\{(99.2) /\left[1+\left(\text { dose } / I_{50}\right)^{1.38}\right]\right\}$ and H-6: $Y=\left\{(100.4) /\left[1+\left(\text { dose } / I_{50}\right)^{3.21}\right]\right\}$. Symbols denoted mean $(n=15) \pm$ standard errors.

\section{Discussion}

\subsection{Dose-Response Assays with Glyphosate}

Growers use glyphosate because it is a highly versatile, broad-spectrum herbicide for weed control. This herbicide has been an important tool to control perennial and annual weeds in crop areas, highlighting the control of perennial weeds in perennial crops, as well as prior to planting or after harvesting in annual crops. Another important aspect is that glyphosate is a herbicide that has high compatibility in mixture with other herbicides with different MOA, increasing its action spectrum. For these reasons, glyphosate has been used excessively. The appearance of resistance to glyphosate in weeds is a problem for growers who are deprived of this effective molecule for weed control.

The observed resistance in $\mathrm{H}-1-\mathrm{H}-5$ populations may be due to numerous herbicide applications over successive years, increases in the recommended field dose, or because the MOA was not changed [14].

Control failures are often due to applications at a later growth stage or because environmental factors during the use of herbicides were ignored [22]. These situations may result in resistance after several years, or a false resistance signal (as a consequence of a bad application and not due to resistance mechanisms). RFs variability between $C$. canadensis populations may be attributed to different resistance mechanisms, and/or the existence of multiple or cross-resistance [23-25].

\subsection{Shikimic Acid Accumulation}

Differential accumulation of shikimic acid between $\mathrm{R}$ and S plants may occurs when glyphosate does not inhibit the EPSPS enzyme mechanisms [13,26,27], due to either target site or non-target site resistance mechanisms [28]. Glyphosate resistant C. canadensis plants could accumulate more shikimic 
acid; however, larger amounts of herbicide would be needed, i.e., an increase in glyphosate doses. The variable accumulation of shikimic acid between the $C$. canadensis populations was in agreement with that observed in the dose-response assays, and other glyphosate resistant Conyza spp. populations from Hungary [29], confirming the resistance to glyphosate of the H-1 to H-5 populations.

\subsection{Dose-Response Assays with Alternative Herbicides}

The results found in the H-6 population treated with flazasulfuron showed that it is an efficient herbicide, but only if an IWM plan is followed with other MOA herbicides. Although not yet reported, multiple resistance flazasulfuron $\times$ glyphosate as a consequence of applying the same herbicide alternatives, it is beginning to be observed in the European Mediterranean region. Some farmers are now reporting low effectiveness due to the continuous use of flazasulfuron over a five year period without alternative MOA herbicides. This effect may soon de observed in Hungary.

\subsection{ALS Enzyme Activity}

In consideration of the results reported here, a goal for further research will be to identify the resistance mechanisms that are involved in both herbicides, glyphosate, and flazasulfuron. For glyphosate, reduced absorption/translocation and/or amino acid substitution(s) are commonly observed [26]; however, for ALS-inhiting herbicides it is not common to see absorption/translocation as the resistance mechanisms $[19,30]$, although it is common to find metabolism and/or amino acid substitution(s) [11,31]. Studying the NTSR and TSR mechanisms endowing resistance to glyphosate and fazasulfuron in the H-8 C. canadensis population may help us to understand how resistance has been selected, as reported recently in many other weed species $[14,32,33]$. We plan to study these mechanisms in the future; meanwhile, taking into account these results, we have determined multiple-resistance to flazasulfuron (ALS-inhibitors) and glyphosate in C. canadensis from Hungary.

Author Contributions: Conceptualization, R.D.P. and A.M.R.-D.; Methodology, R.A.d.l.C., P.T.F.-M., and A.M.R.-D.; Software, R.A.d.l.C. and P.T.F.-M.; Validation, R.D.P.; Formal Analysis, R.A.d.l.C. and A.M.R.-D.; Investigation, A.M.R.-D., R.A.d.l.C., P.T.F.-M., B.K.T., and C.P.-B.; Resources, R.D.P.; Data Curation, P.T.F.-M.; Writing-Original Draft Preparation, A.M.R.-D.; Writing-Review and Editing, R.D.P. and A.M.R.-D.; Visualization, R.A.d.1.C.; Supervision, R.D.P.; Project Administration, R.D.P.; Funding Acquisition, R.D.P.

Funding: This research received no external funding.

Acknowledgments: We are grateful to Rafael Roldan-Gomez and Antonio Jesus Garcia-Romero for technical assistance in the completion of this research. This work was funded by the Spanish Ministry of Economy and Competitiveness (AGL2016-78944-R), and partially by Monsanto Europe S.A. (Brussels). Phillip Villani (The University of Melbourne) revised and corrected the English language used in this manuscript.

Conflicts of Interest: The authors declare no conflict of interest.

\section{References}

1. HRAC-Herbicide Resistance Action Committee (2018) Confirming resistance. Available online: http:// hracglobal.com/herbicide-resistance/confirming-resistance (accessed on 7 January 2018).

2. Sammons, R.D.; Gaines, T.A. Glyphosate resistance: State of knowledge. Pest Manag. Sci. 2014, 70, 1367-1377. [CrossRef] [PubMed]

3. Benbrook, C.M. Trends in glyphosate herbicide use in the United States and globally. Environ. Sci. Eur. 2016, 28, 3. [CrossRef] [PubMed]

4. Heap, I.; Duke, S.O. Overview of glyphosate-resistant weeds worldwide. Pest Manag. Sci. 2018, 74, 1040-1049. [CrossRef] [PubMed]

5. González-Torralva, F.; Rojano-Delgado, A.M.; de Castro, M.D.L.; Mülleder, N.; De Prado, R. Two non-target mechanisms are involved in glyphosate-resistant horseweed (Conyza canadensis L. Cronq.) biotypes. J. Plant Physiol. 2012, 169, 1673-1679. [CrossRef] [PubMed]

6. González-Torralva, F.; Gil-Humanes, J.; Barro, F.; Domínguez-Valenzuela, J.A.; De Prado, R. First evidence for a target site mutation in the EPSPS2 gene in glyphosate-resistant Sumatran fleabane from citrus orchards. Agron. Sustain. Dev. 2014, 34, 553-560. [CrossRef] 
7. Kleinman, Z.; Rubin, B. Non-target-site glyphosate resistance in Conyza bonariensis is based on modified subcellular distribution of the herbicide. Pest Manag. Sci. 2017, 73, 246-253. [CrossRef] [PubMed]

8. VanGessel, M.J. Glyphosate-resistant horseweed from Delaware. Weed Sci. 2001, 49, 703-705. [CrossRef]

9. Ge, X.; d'Avignon, D.A.; Ackerman, J.J.; Sammons, R.D. Rapid vacuolar sequestration: The horseweed glyphosate resistance mechanism. Pest Manag. Sci. 2010, 66, 345-348. [CrossRef] [PubMed]

10. Rojano-Delgado, A.M.; Cruz-Hipolito, H.; De Prado, R.; Castro, M.D.L.; Franco, A.R. Limited uptake, translocation and enhanced metabolic degradation contribute to glyphosate tolerance in Mucuna pruriens var. utilis plants. Phytochemistry 2012, 73, 34-41. [CrossRef] [PubMed]

11. Rojano-Delgado, A.M.; Priego-Capote, F.; de Castro, M.D.L.; De Prado, R. Mechanism of imazamox resistance of the Clearfield ${ }^{\circledR}$ wheat cultivar for better weed control. Agron. Sustain. Dev. 2015, 35, 639-648. [CrossRef]

12. Délye, C. Unravelling the genetic bases of non-target-site-based resistance (NTSR) to herbicides: A major challenge for weed science in the forthcoming decade. Pest Manag. Sci. 2013, 69, 176-187. [CrossRef] [PubMed]

13. Gherekhloo, J.; Fernández-Moreno, P.T.; Alcántara-de la Cruz, R.; Sánchez-González, E.; Cruz-Hipolito, H.E.; Dominguez-Valenzuela, J.A.; De Prado, R. Pro-106-Ser mutation and EPSPS overexpression acting together simultaneously in glyphosate-resistant goosegrass (Eleusine indica). Sci. Rep. 2017, 7, 6702. [CrossRef] [PubMed]

14. Fernández, P.; Alcántara, R.; Osuna, M.D.; Vila-Aiub, M.M.; Prado, R. Forward selection for multiple resistance across the non-selective glyphosate, glufosinate and oxyfluorfen herbicides in Lolium weed species. Pest Manag. Sci. 2017, 73, 936-944. [CrossRef] [PubMed]

15. FAO-Food and Agriculture Organization of the United Nations. ECA/40/17/INF/4 rev.1. Available online: http:/ / www.fao.org/3/a-mu357s.pdf (accessed on 8 December 2017).

16. Hess, M.; Barralis, G.; Bleiholder, H.; Buhr, L.; Eggers, T.H.; Hack, H.; Stauss, R. Use of the extended BBCH scale-general for the descriptions of the growth stages of mono; and dicotyledonous weed species. Weed Res. 1997, 37, 433-441. [CrossRef]

17. Dayan, F.E.; Owens, D.K.; Corniani, N.; Silva, F.M.L.; Watson, S.B.; Howell, J.L.; Shaner, D.L. Biochemical markers and enzyme assays for herbicide mode of action and resistance studies. Weed Sci. 2015, 63, $23-63$. [CrossRef]

18. Hanson, B.D.; Shrestha, A.; Shaner, D.L. Distribution of glyphosate-resistant horseweed (Conyza canadensis) and relationship to cropping systems in the central valley of California. Weed Sci. 2009, 57, 48-53. [CrossRef]

19. Hatami, Z.M.; Gherekhloo, J.; Rojano-Delgado, A.M.; Osuna, M.D.; Alcántara, R.; Fernández, P.; Sadeghipour, H.R.; De Prado, R. Multiple mechanisms increase levels of resistance in Rapistrum rugosum to ALS herbicides. Front. Plant Sci. 2016, 7, 169. [CrossRef] [PubMed]

20. Bradford, M.M. A rapid and sensitive method for the quantitation of microgram quantities of protein utilizing the principle of protein dye binding. Anal. Biochem. 1976, 72, 248-254. [CrossRef]

21. Ritz, C.; Baty, F.; Streibig, J.C.; Gerhard, D. Dose-response analysis using R. PLoS ONE 2015, 10 , e0146021. [CrossRef] [PubMed]

22. Tornisielo, V.L.; Botelho, R.G.; Alves, P.A.T.; Bonfleur, E.J.; Monteiro, S.H. Pesticide tank mixes: An environmental point of view. In Herbicides-Current Research and Case Studies in Use; Price, A., Ed.; Intech Open: London, UK, 2013; pp. 473-487.

23. Bracamonte, E.; Fernández-Moreno, P.T.; Barro, F.; De Prado, R. Glyphosate-resistant Parthenium hysterophorus in the Caribbean islands: Non target site resistance and target site resistance in relation to resistance levels. Front. Plant Sci. 2016, 7, 1845. [CrossRef] [PubMed]

24. Dominguez-Valenzuela, J.A.; Gherekhloo, J.; Fernández-Moreno, P.T.; Cruz-Hipolito, H.E.; Alcántara-de la Cruz, R.; Sánchez-González, E.; De Prado, R. First confirmation and characterization of target and non-target site resistance to glyphosate in Palmer amaranth (Amaranthus palmeri) from Mexico. Plant Physiol. Biochem. 2017, 115, 212-218. [CrossRef] [PubMed]

25. González-Torralva, F.; Cruz-Hipolito, H.; Bastida, F.; Mülleder, N.; Smeda, R.J.; De Prado, R. Differential susceptibility to glyphosate among the Conyza weed species in Spain. J. Agric. Food Chem. 2010, 58, 4361-4366. [CrossRef] [PubMed] 
26. Alcántara-de la Cruz, R.; Fernández-Moreno, P.T.; Ozuna, C.V.; Rojano-Delgado, A.M.; Cruz-Hipolito, H.E.; Domínguez-Valenzuela, J.A.; Barro, F.; De Prado, R. Target and non-target site mechanisms developed by glyphosate-resistant Hairy beggarticks (Bidens pilosa L.) populations from Mexico. Front. Plant Sci. 2016, 7, 1492. [CrossRef] [PubMed]

27. Shaner, D.L.; Nadler-Hassar, T.; Henry, W.B.; Koger, C.H. A rapid in vivo shikimate accumulation assay with excised leaf discs. Weed Sci. 2005, 53, 769-774. [CrossRef]

28. Bracamonte, E.; Silveira, H.M.; Alcántara-de la Cruz, R.; Domínguez-Valenzuela, J.A.; Cruz-Hipolito, H.E.; De Prado, R. From tolerance to resistance: Mechanisms governing the differential response to glyphosate in Chloris barbata. Pest Manag. Sci. 2018, 74, 1118-1124. [CrossRef] [PubMed]

29. Tahmasebi, B.K.; Alebrahim, M.T.; Roldán-Gómez, R.A.; Silveira, H.M.; Carvalho, L.B.; Alcántara-de la Cruz, R.; De Prado, R. Effectiveness of alternative herbicides on three Conyza species from Europe with and without glyphosate resistance. Crop Prot. 2018, 112, 350-355. [CrossRef]

30. Cruz-Hipolito, H.; Rosario, J.; Ioli, G.; Osuna, M.D.; Smeda, R.J.; González-Torralva, F.; De Prado, R. Resistance mechanism to tribenuron-methyl in white mustard (Sinapis alba) from southern Spain. Weed Sci. 2013, 61, 341-347. [CrossRef]

31. Zheng, D.; Kruger, G.R.; Singh, S.; Davis, V.M.; Tranel, P.J.; Weller, S.C.; Johnson, W.G. Cross-resistance of horseweed (Conyza canadensis) populations with three different ALS mutations. Pest Manag. Sci. 2011, 67, 1486-1492. [CrossRef] [PubMed]

32. Byker, H.P.; Soltani, N.; Robinson, D.E.; Tardif, F.J.; Lawton, M.B.; Sikkema, P.H. Occurrence of glyphosate and cloransulam resistant Canada fleabane (Conyza canadensis L. Cronq.) in Ontario. Can. J. Plant Sci. 2013, 93, 851-855. [CrossRef]

33. Matzrafi, M.; Lazar, T.W.; Sibony, M.; Rubin, B. Conyza species: Distribution and evolution of multiple target-site herbicide resistances. Planta 2015, 242, 259-267. [CrossRef] [PubMed]

(C) 2018 by the authors. Licensee MDPI, Basel, Switzerland. This article is an open access article distributed under the terms and conditions of the Creative Commons Attribution (CC BY) license (http:/ / creativecommons.org/licenses/by/4.0/). 